doi: $10.15407 /$ ukrbotj72.06.574

\author{
S.Y. KONDRATYUK ${ }^{1}$, J.A. KIM², N.-H. YU², M.-H. JEONG ${ }^{2}$, S.H. JANG ${ }^{2}$, A.S. KONDRATIUK ${ }^{2,3}$, \\ B. ZAREI-DARKI ${ }^{4}$, J.-S. HUR ${ }^{2}$ \\ ${ }^{1}$ M.G. Kholodny Institute of Botany, National Academy of Sciences of Ukraine \\ 2, Tereshchenkivska Str., Kyiv, 01004,Ukraine \\ ksya_net@ukr.net \\ ${ }^{2}$ Korean Lichen Research Institute, Sunchon National University \\ Sunchon 540-742, Korea \\ jshur1@sunchon.ac.kr \\ ${ }^{3}$ Institute of Biology, Scientific Educational Centre, Taras Shevchenko National University of Kyiv \\ 64/13, Volodymyrska Str., Kyiv, 01601, Ukraine \\ tyukondra@gmail.com \\ ${ }^{4}$ Tarbiat Modares University \\ Jalal Ale Ahmad Highway 14115-318, Tehran, Iran \\ zareidarki@modares.ac.ir
}

\title{
ZEROVIELLA, A NEW GENUS OF XANTHORIOID LICHENS (TELOSCHISTACEAE, ASCOMYCOTA) PROVED BY THREE GENE PHYLOGENY
}

\begin{abstract}
Kondratyuk S.Y., Kim J.A., Yu N.-H., Jeong M.-H., Jang S.H., Kondratiuk A.S., Zarei-Darki B., Hur J.-S. Zeroviella, a new genus of xanthorioid lichens (Teloschistaceae, Ascomycota) proved by three gene phylogeny. Ukr. Bot. J. - 2015. - 72(6): 574-584.

A new genus, Zeroviella S.Y. Kondr. \& J.-S. Hur (Xanthorioideae, Teloschistaceae) for the widely distributed in the Palearctic Rusavskia papillifera-group is proposed on the basis of a combined phylogenetic data set based on ITS and LSU nrDNA and 12S SSU mtDNA sequences. A new species from Palearctic, Zeroviella esfahanensis S.Y. Kondr., B. Zarei-Darki \& J.S. Hur, is described, illustrated and compared with closely related taxa. Seven new combinations for the genus Zeroviella (Zeroviella coreana (S.Y. Kondr. \& J.-S. Hur) S.Y. Kondr. \& J.-S. Hur, Z. digitata (S.Y. Kondr.) S.Y. Kondr. \& J.-S. Hur, Z. domogledensis (Vězda) S.Y. Kondr. \& J.-S. Hur, Z. laxa (Müll. Arg.) S.Y. Kondr. \& J.-S. Hur, Z. mandschurica (A. Zahlbr.) S.Y. Kondr. \& J.-S. Hur, Z. papillifera (Vain.) S.Y. Kondr. \& J.-S. Hur, and Z. ussurica (S.Y. Kondr. \& J.-S. Hur) S.Y. Kondr. \& J.-S. Hur) are proposed. Additionally, seven new combinations for various genera of the Teloschistaceae (i.e.: Blastenia catalinae (H. Magn.) E.D. Rudolf, Fulgogasparrea brouardii (B. de Lesd.) S.Y. Kondr., Scythioria duritzii (H. Magn.) S.Y. Kondr., Scythioria flavogranulosa (Arup) S.Y. Kondr., Sirenophila cliffwetmorei (S.Y. Kondr. \& Kärnefelt) S.Y. Kondr., Squamulea nesodes (Poelt \& Nimis) S.Y. Kondr., and Villophora microphyllina (Tuck.) S.Y. Kondr.) are proposed.
\end{abstract}

K e y w o r d s: Rusavskia, Zeroviella esfahanensis, Scythioria, Fulgogasparrea, Blastenia

\section{Introduction}

The taxonomy of the Teloschistaceae has developed rapidly since 2012. A large number of new genera, based on molecular phylogeny investigations, have been proposed (Arup et al., 2013a; Fedorenko et al., 2012; Gaya et al., 2012; Kondratyuk et al., 2013b, 2014a,b, 2015a,c,d). The number of genera in the Teloschistaceae increased from 10 in Kärnefelt (1989) to 29 (Arup et al., 2013a) and presently to 78 (Kondratyuk et al., 2013b, 2014a, b, 2015a, c, d; Søchting et al. 2014a, b). The family is divided in three, Caloplacoideae, Teloschistoideae, and Xanthorioideae (Gaya et al., 2012; Arup et al., 2013b) or four subfamilies (Kondratyuk et al., 2015d) (Table 1).

(C) S.Y. KONDRATYUK, J.A. KIM, N.-H. YU, M.-H. JEONG, S.H. JANG, A.S. KONDRATIUK, B. ZAREI-DARKI, J.-S. HUR, 2015

The genus Rusavskia S.Y. Kondr. \& Kärnefelt was described in 2003 (Kondratyuk, Kärnefelt, 2003) on the basis of morphological, anatomical and chemical data, and for a long time was not accepted (because it was named as 'morphological' taxon). The Rusavskia elegans-group (or as Xanthoria elegans-group) as a separate monophyletic branch was confirmed by various authors (Fedorenko et al., 2009, 2012; Gaya et al., 2012; Arup et al. 2013a; Kondratyuk et al., 2014b) after nrDNA and mtDNA sequences. This genus was accepted in Arup et al. paper (2013a). However, the genus Rusavskia was not well accepted till 2015.

Within our study, the Rusavskia branch was found to be polyphyletic. The further collection of molecular data on members of the genus Rusavskia appeared to show that this genus includes two or three monophyletic groups which are characterized by the highest level of bootstrap support. These three groups are the following: 
Table 1. Genera of four subfamilies of the Teloschistaceae*

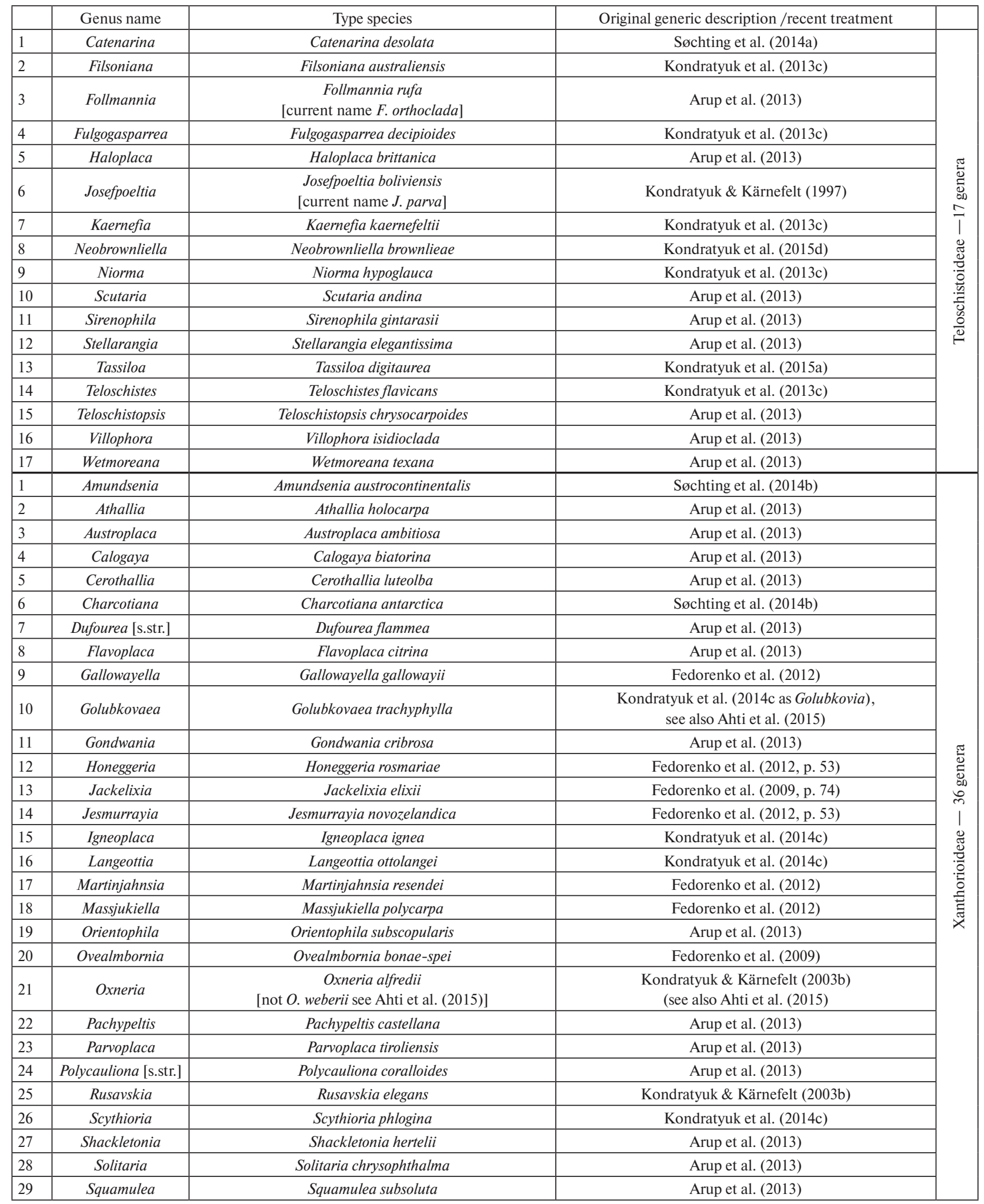

*Cited papers should be consulted for author names of taxa listed. 
Continuation Table 1. Genera of four subfamilies of the Teloschistaceae*

\begin{tabular}{|c|c|c|c|c|}
\hline & Genus name & Type species & Original generic description /recent treatment & \\
\hline 30 & Verrucoplaca & Verrucoplaca verruculifera & Kondratyuk et al. (2014c) & \multirow{7}{*}{ 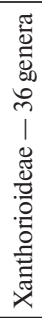 } \\
\hline 31 & Xanthocarpia & Xanthocarpia ochracea & Arup et al. (2013) & \\
\hline 32 & Xanthokarroa & Xanthokarroa karrooensis & Fedorenko et al. (2009) & \\
\hline 33 & $\begin{array}{l}\text { Xanthomendoza } \\
\text { [s.str.] }\end{array}$ & Xanthomendoza mendoza & Kondratyuk \& Kärnefelt (1997) & \\
\hline 34 & Xanthopeltis & Xanthopeltis rupicola & Arup et al. (2013) & \\
\hline 35 & Xanthoria [s.str.] & Xanthoria parietina & Fedorenko et al. $(2009,2012)$ & \\
\hline 36 & Zeroviella & Zeroviella papillifera & This paper & \\
\hline 1 & Blastenia & Blastenia ferruginea & Kondratyuk et al. (2014a) & \multirow{17}{*}{ 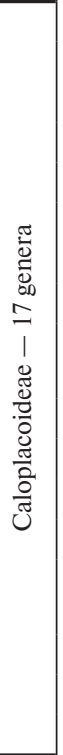 } \\
\hline 2 & Bryoplaca & Bryoplaca sinapisperma & Arup et al. (2013) & \\
\hline 3 & Caloplaca & Caloplaca cerina & Kondratyuk et al. (2014a) & \\
\hline 4 & Eilifdahlia & Eilifdahlia dahlii & Kondratyuk et al. (2014a) & \\
\hline 5 & Elenkiniana & Elenkiniana gloriae & Kondratyuk et al. (2014a) & \\
\hline 6 & Franwilsia & Franwilsia bastowii & Kondratyuk et al. (2014a) & \\
\hline 7 & Gyalolechia s.str. & Gyalolechia aurea & Arup et al. (2013) & \\
\hline 8 & Huneckia & Huneckia pollinii & Kondratyuk et al. (2014a) & \\
\hline 9 & Ioplaca & $\begin{array}{c}\text { Ioplaca sphalera } \\
\text { [current name I. pindarensis (Räsänen) Poelt \& Hinter.] }\end{array}$ & Arup et al. (2013) & \\
\hline 10 & Leproplaca & \begin{tabular}{|c|} 
Leproplaca xantholyta \\
\end{tabular} & Arup et al. (2013) & \\
\hline 11 & Mikhtomia & Mikhtomia gordejevii & Kondratyuk et al. (2014a) & \\
\hline 12 & Pyrenodesmia & Pyrenodesmia chalybaea & Arup et al. (2013) & \\
\hline 13 & Rufoplaca & Rufoplaca subpallida & Arup et al. (2013) & \\
\hline 14 & Seirophora & $\begin{array}{c}\text { Seirophora magara } \\
\text { [current name Seirophora villosa] }\end{array}$ & Arup et al. (2013) & \\
\hline 15 & Usnochroma & Usnochroma carphinea & Arup et al. (2013) & \\
\hline 16 & Variospora & Variospora velana & Arup et al. (2013) & \\
\hline 17 & Yoshimuria & Yoshimuria spodoplaca & Kondratyuk et al. (2014a) & \\
\hline 1 & Brownliella & $\begin{array}{c}\text { Brownliella aequata } \\
\text { [current name Brownliella kobeana] }\end{array}$ & Kondratyuk et al. (2013c, 2015d) & $\underset{\frac{\pi}{0}}{=}$ \\
\hline 2 & Lazarenkoella & Lazarenkoella zoroasteriorum & Kondratyuk et al. (2015d) & $\begin{array}{l}\infty \\
\infty \\
\infty\end{array}$ \\
\hline 3 & Marchantiana & Marchantiana occidentalis & Kondratyuk et al. (2014a) & 1 \\
\hline 4 & Raesaeneniana & Raesaeneniana maulensis & Kondratyuk et al. (2015d) & $\underset{\varpi}{\pi}$ \\
\hline 5 & Streimanniella & Streimanniella michelagoensis & Kondratyuk et al. (2015d) & $\overline{0}$ \\
\hline 6 & Tarasginia & Tarasginia whinrayi & Kondratyuk et al. (2015d) & 三 \\
\hline 7 & Tayloriella & Tayloriella erythrosticta & Kondratyuk et al. (2015d) & ô \\
\hline 8 & Thelliana & Thelliana pseudokiamae & Kondratyuk et al. (2015d) & \\
\hline
\end{tabular}

${ }^{*}$ Cited papers should be consulted for author names of taxa listed

the Rusavskia elegans-group, the $R$. papillifera-group and the species Zeroviella esfahanensis described below.

The Rusavskia elegans-group includes the type species of the genus as well as $R$. sorediata and $R$. dasanensis, all widely distributed taxa; the first two are cosmopolitan bipolar taxa, while $R$. dasanensis is known so far from Eurasia only.

The Rusavskia papillifera-group includes $R$. papillifera, and $R$. mandschurica, known from the first half of the last century, and three more or less recently described taxa, i.e. $R$. digitata, $R$. ussurica and $R$. coreana. Among these taxa only $R$. papillifera was recorded from all continents of the Northern Hemisphere (Europe, Asia, North America), while all these data are in urgent need of revision. $R$. digitata is so far a South-Eastern European endemic taxon, and $R$. coreana, $R$. mandschurica and $R$. ussurica are known only from Eastern Asian region.

Zeroviella esfahanensis represents the third group, which is located in somewhat intermediate position between Rusavskia and Zeroviella after different analyses when various taxa / numbers of species are included into analysis. 
Table 2. Specimens of the genera Rusavskia and Zeroviella included in the phylogenetic analysis and their GenBank accession numbers

\begin{tabular}{|c|c|c|c|c|}
\hline Species name & Voucher details / references & ITS & LSU & mtDNA \\
\hline Rusavskia dasanensis & SK 653 Russia, 2011. I.A.Galanina 3-28, this paper & KU056845 & & KU043371 \\
\hline Rusavskia dasanensis & SK 702, China CH 090097 (KoLRI 010711), this paper & KU056846 & & KU043372 \\
\hline Rusavskia dasanensis & $\begin{array}{c}\text { SK 769, Norway, Svalbard } \\
\text { Archipelago, Spitsbergen, } \\
\text { 2009, Hur, J.-S. (ARCT 09028) KoLRI-011123, (Kondratyuk et al., 2014b) }\end{array}$ & KJ133479 & & \\
\hline Rusavskia dasanensis & $\begin{array}{l}\text { SK 773, Norway, Svalbard } \\
\text { Archipelago, Spitsbergen, 2009, Hur, J.-S. ARCT } 09028 \text { (KoLRI 011123), this paper }\end{array}$ & KU056847 & & \\
\hline Rusavskia elegans & FNM 019, Ukraine, Kondratyuk 20350 et al. $(K W-L)$; Fedorenko et al. (2009) & EU681336 & & EU680921 \\
\hline Rusavskia elegans & Arup et al.(2013a) & & KC179238 & KC179576 \\
\hline Rusavskia sorediata & Norway, 2003 Lindblom 1229 (BG) Lindblom, Ekman (2005) & AY453647 & & \\
\hline Rusavskia sorediata & E. Gaya 367, A. Gomez-Bolea \& Arino (BCN) Gaya et al. $(2003,2008)$ & EU639643* & & \\
\hline Rusavskia sorediata & Søchting et al. (2002) & AY081153 & & \\
\hline Rusavskia sorediata & 046 Finland, Haikonen 24238(H); Fedorenko et al. (2009) & EU681335 & & EU680920 \\
\hline Rusavskia sorediata & Arup et al.(2013a) & & KC179239 & KC179577 \\
\hline Zeroviella coreana & $\begin{array}{l}\text { SK D06, Republic of Korea. Cheju-do province: Chejudo island, 19.06.2014 } \\
\text { Kondratyuk, S. Y. (02), Lőkös, L., Oh, S.-O., Hur, J.-S. (140327) (isotype: } \\
\text { KoLRI 022689), this paper. }\end{array}$ & KU056848 & & KU043373 \\
\hline Zeroviella digitata & FNM 191, Ukraine, Kondratyuk 204158 ( $K W-L)$; Fedorenko et al. (2009) & EU681338 & & EU680923 \\
\hline Zeroviella esfahanensis & SK 501, Iran: Karkas, 2010 B. Zarei-Darki 1336 ( $K W-L-$ holotype), this paper & KU056849 & & KU043374 \\
\hline Zeroviella esfahanensis & SK 502, Iran: Karkas, 2010 B. Zarei-Darki $1069(K W-L)$, this paper & KU056850 & & KU043375 \\
\hline Zeroviella esfahanensis & SK 505, Iran: Karkas, 2010 B. Zarei-Darki $15(K W-L)$, this paper & KU056851 & & KU043376 \\
\hline Zeroviella esfahanensis & SK 506, Iran: Karkas, 2010 B. Zarei-Darki 2(1) $(K W-L)$, this paper & KU056852 & & KU043377 \\
\hline Zeroviella esfahanensis & $\begin{array}{l}\text { SK 3193, Spain, Tenerife, } 2009 \text { S.Y. Kondratyuk } 20909 \text { (KW-L), (Fedorenko et } \\
\text { al. } 2012 \text { as Rusavskia elegans) }\end{array}$ & JN984133 & & \\
\hline Zeroviella laxa & SK751, China: CH080120 (KoLRI 008988), this paper & KU056853 & & KU043378 \\
\hline Zeroviella laxa & SK753, China: CH 100017 (KoLRI 011881), this paper & KU056854 & & \\
\hline Zeroviella mandschurica & SK 698, China, CH090091 (KoLRI 010705), this paper & KU056855 & & \\
\hline Zeroviella mandschurica & SK 703, China CH 090097 (KoLRI 010711), this paper & KU056856 & & \\
\hline Zeroviella papillifera & FNM 018, Ukraine, Kondratyuk 20350 et al. $(K W-L)$; Fedorenko et al. (2009) & EU681331 & & EU680927 \\
\hline Zeroviella papillifera & FNM 203, Iran, Sohrabi 4000( $K W-L)$; Fedorenko et al. (2009) & EU681339 & & EU680925 \\
\hline Zeroviella papillifera & FNM 204, Ukraine, Smerychyns'ka 0313(2)(KW-L); Fedorenko et al. (2009) & EU681330 & & EU680926 \\
\hline Zeroviella ussurica & $\begin{array}{c}\text { SK D08, Russia: Primorsky region: Khasan district, Zapredeljnoe settlement, } \\
\text { Khaldoj Bay, Cape Bruce, 05.08.2013 S.Y. Kondratyuk RU130397 (KoLRI } \\
\text { 019924 - isotype), this paper }\end{array}$ & KU056857 & & KU043379 \\
\hline Zeroviella ussurica & $\begin{array}{l}\mathbf{0 8 0 2 5 2} \text { KoLRI, South Korea, } 37^{\circ} 35^{\prime} 02.1^{\prime \prime} \mathrm{N}, 128^{\circ} 54^{\prime} 00.4^{\prime \prime E} 1058 \mathrm{~m} \text { alt., } \\
24.05 .2008080252 \text { KoLRI } 008498 \text {, this paper }\end{array}$ & KU056858 & & \\
\hline Zeroviella ussurica & $\begin{array}{l}090032 \text { KoLRI, South Korea, } 33^{\circ} 33^{\prime} 53.6^{\prime \prime} \mathrm{N}, 126^{\circ} 46^{\prime} 24.9^{\prime \prime E}, 5 \mathrm{~m} \text { alt., } 19.04 .2009 \\
090032 \text { KoLRI 009796, this paper }\end{array}$ & KU056859 & & \\
\hline Zeroviella ussurica & $\begin{array}{c}\mathbf{0 7 0 1 2 5} \text { KoLRI, South Korea, } 34^{\circ} 00^{\prime} 38.9^{\prime \prime} \mathrm{N}, 127^{\circ} 19^{\prime} 09.2^{\prime \prime E}, 27 \mathrm{~m} \text { alt., } 24.03 .2007 \\
070125 \text { KoLRI } 007112 \text {, this paper }\end{array}$ & KU056860 & & \\
\hline
\end{tabular}

A new genus was discovered within this study and is described below as Zeroviella for the widely distributed in the Palearctic Rusavskia papillifera-group. Furthermore, one new for science species of this genus, Zeroviella esfahanensis, from Palearctic is also described and illustrated below.

\section{Materials and methods}

Specimens were examined using standard microscopical techniques, i.e. hand-sectioned under a Nikon SMZ645 dissecting microscope (Nikon Corp., Tokyo,
Japan), sections were observed under a Nikon E-200 and Olympus BX-51 microscope (same as above). Spot test reactions were performed on thalli. Chemicals were extracted in analytical grade acetone in a $1 \mathrm{~mL}$ Eppendorf tube. Thin layer chromatography (TLC) was performed using a glass plate coated with TLC Silica gel 60, in solvent system A (toluene : dioxin : acetic acid = 180:45:5) (Orange et al., 2010).

Voucher specimens of the genera Rusavskia and Zeroviella included in the phylogenetic analyses are listed (table 2), while the members of the other genera 
of the Teloschistaceae included in the phylogenetic tree (Fig. 1) are cited in our previous paper (Kondratyuk et al., 2014a,b).

Total DNA was extracted directly from the thalli according to Ekman (1999) and was purified with DNeasy Plant Mini Kit (QIAGEN, Germany). The nuclear ribosomal RNA gene region including the internal transcribed spacers 1 and 2 and the 5.8S subunit (ITS) was amplified using the primers ITS1F (Gardes, Bruns, 1993) and ITS4 (White et al., 1990), the 28S LSU using the primer LR5 (Vilgalys, Hester, 1990), and the $12 \mathrm{~S} \mathrm{mtSSU}$ using the primers mtSSU1-mtSSU3R and mtSSU2R (Fedorenko et al. 2009, 2012).

The amplification was done using a Takara JP/TP600 PCR machine (Takara Bio Inc., Japan). One initial cycle of $5 \mathrm{~min}$ at $94^{\circ} \mathrm{C}$ was followed by 30 cycles of the following steps: 30 seconds at $94{ }^{\circ} \mathrm{C}, 39$ seconds at 57 ${ }^{\circ} \mathrm{C}$ and $1 \mathrm{~min}$ at $72{ }^{\circ} \mathrm{C}$. Amplifications were ended with a final cycle at $72{ }^{\circ} \mathrm{C}$ for $10 \mathrm{~min}$. PCR products were then sent to the sequencing facilities of the Genotech Cooperation, Seoul, South Korea for cleaning and sequencing. The sequencing was carried out using the fluorescent marker BigDye and an ABI 3730xl sequencing machine (Applied Biosystems, Carlsbad, CA, USA).

The consensus sequence was aligned with all related species sequences retrieved from the GenBank database. The consensus sequences were then deposited into GenBank under the accession numbers KU043371KU043379 and KU056845-KU056860. Phylogenetic analysis was performed using the ITS region and LSU gene of nrDNA and 12S SSU mtDNA sequences of the treated fungi retrieved from the GenBank database and the 7 lichen-forming fungi investigated in this study. Sequence alignment was conducted in BioEdit and a phylogenetic tree was generated by the maximum parsimony (MP), minimum evolution (ME), and maximum likelihood (ML) analysis methods performed in Mega 5.0 (Tamura et al. 2011) with the number of bootstrap trials set to 1,000 .

Altogether 25 sequences on nrDNA and mtDNA are submitted to GenBank.

\section{Results and discussion}

\section{Description of taxa}

Zeroviella S.Y. Kondr. et J.-S. Hur, gen. nov.

MycoBank No. MB 814860

Thallus saxicolous, foliose, yellow, orange to reddish orange, attached to the substratum by lower side. Both cortical layers paraplectenchymatous, medullary layer without well-developed hollow. Apothecia zeorine/ lecanorine, true excipulum scleroplectenchymatous. Conidia narrowly elongate, bacilliform. Constituents: parietin (major compound), teloschistin, fallacinal, parietinic acid and emodin (traces).

Type species: Zeroviella papillifera (Vain.) S.Y. Kondr. et J.-S. Hur.

Thallus saxicolous or muscisolous, distinctly foliose, rather thick, yellow, orange to reddish orange, with or without soredia or isidia, attached to the substratum by lower side. Corticate on both side, both upper and lower cortical layers paraplectenchymatous, medullary layer moderately developed, without welldeveloped hollow. Apothecia zeorine/lecanorine, sessile, disc concave, becoming plane at maturity, with thalline margin, concolorous with thallus, true excipulum scleroplectenchymatous, cortical layer of thalline margin paraplectenchymatous. Asci clavate, of Teloschistes-type. Ascospores colourless, ellipsoidal, polarilocular. Conidia narrowly elongate, bacilliform.

Chemistry: Thallus $\mathrm{K}+$ purple. Constituents: parietin (major compound), teloschistin, fallacinal, parietinic acid and emodin (traces).

Ecology: Known from the coastal regions, where it grows abundantly on large siliceous boulders (rocks) both on subvertical and horizontal faces exposed to the sun along to high altitudes in mountainous regions especially in areas with limestone outcrops.

Species diversity: The genus includes so far 7 species, of which Zeroviella papillifera is the most widely distributed. Z. mandschurica and newly described R. esfahanensis are rather widely recorded within Asian continent while the other taxa ( $Z$. coreana, $Z$. digitata, and $Z$. ussurica) are more restrictedly distributed.

Distribution: Zeroviella is presently rather widely distributed genus in the Palearctic (Europe, Asia and North Africa), while a few records of the type species Zeroviella papillifera from the Northern American continent are still in need of further confirmation.

Etymology: The genus honours the Ukrainian botanist Prof. Dmytro K. Zerov (1895-1971) (Kyiv, Ukraine), the founder of the Bryological Herbarium in KW, the founder of Kiev bryological scientific school and Ukrainian paleobotanic scientific school, to acknowledge his contributions, especially to the Eurasian flora of liverworts and sphagnous mosses.

Taxonomic notes: The members of the genus Zeroviella were previously placed in the Rusavskia s.l. However, the further accumulation of molecular data on this branch have shown the Zeroviella branch to be 
separate robust monophyletic branch, while the level of the whole Rusavskia clade is rather weak.

The representatives of the genus Zeroviella differ from the members of the genus Rusavskia in having both paraplectenchymatous cortical layers of thallus (vs. mainly scleroplectenchymatous or with larger portion of scleroplectenchymatous tissue underlining very narrow paraplectenchymatous layer), in having much thinner thalline lobes owing to the lack of welldeveloped hollow in the medullar, as well as usually welldeveloped pseudocyphellae. Furthermore, the genus Zeroviella differs from the Rusavskia in having much thinner thalline lobes which seem to be convex owing to bent dawnwards edges (vs. thalline lobes very convex and usually with well-developed hollow medullar), in having mainly Mediterranean and Eastern Eurasian distribution (vs. bipolar distribution and high altitudes of all continents) as well as in positioning in separate monophyletic branch after combined phylogenetic analysis.

It should be mentioned that the Rusavskia clade, segregated for the first time in 2009 by Fedorenko et al. (2009), was characterized by rather low level of support. With addition of new data on Rusavskia species as well as especially on the Rusavskia papillifera-group, level of this support became even lower, while Zeroviella is a well supported robust branch.

It should be mentioned that a number of voucher specimens, molecular data on which were submitted to the GenBank as 'Xanthoria elegans' belong to the genus Rusavskia s.str., i.e. the Rusavskia elegans-group. However, there are also specimens, which are without doubt members of the Zeroviella esfahanensis branch and the Zeroviella clade. These vouchers are in urgent need of further revision based on morphological and anatomical characters.

Furthermore, it should be stressed that there are also a number of vouchers selected from Antarctica, AF278753-AF278757, named as Rusavskia elegans in the GenBank (and published by Dyer \& Murtagh 2001 as Xanthoria elegans), which in fact are members of the genus Calogaya Arup, Frödén \& Søchting.

The Zeroviella mandschurica-group is probably one of the Eastern Asian species group similarly to the genera Nipponoparmelia (Kurok.) K.H. Moon, Y. Ohmura \& Kashiw. (Kondratyuk et al., 2013d), Kashiwadia S.Y. Kondr., L. Lőkös, et J.-S. Hur (Kondratyuk et al., 2014c), Ivanpisutia S. Y. Kondr., L. Lőkös et J.-S. Hur (Kondratyuk et al., 2015b), Orientophila Arup, Søchting
\& Frödén, Yoshimuria S.Y. Kondr., Kärnefelt, Elix, A. Thell et J.-S. Hur, Jasonhuria S.Y. Kondr., L. Lőkös et S.-O. Oh or Loekoesia S.Y. Kondr., S.-O. Oh et J.-S. Hur (Kondratyuk et al., 2014 a, b, 2015c) recently found to include only (or predominantly) Eastern Asian taxa (having the centre of species diversity in Eastern Asia), forming separate robust monophyletic branches in the phylogenetic trees of different families of the lichen-forming fungi.

As members of the same Rusavskia clade, both genera Zeroviella and Rusavskia are characterized by narrowly bacilliform conidia and the lack of any specialized organs of attachment to the substrate. The representatives of the genus Rusavskia, after original description (Kondratyuk, Kärnefelt, 2003), differ from the other Xanthorias by lack of special organs of attachment to the substrate, lax medulla very often with well-developed hollow, anatomical characters of apothecia and thallus, bacilliform conidia and parietin chemosyndrom.

Zeroviella esfahanensis S.Y. Kondr., B. Zarei-Darki \& J.S. Hur, sp. nov. $\quad$ Figs. 2-3.

MycoBank No. MB 814861

Similar to Rusavskia mandschurica but differs in having shorter and wider thalline lobes, in having paraplectenchymatous thalline exciple and narrower ascospore septum.

TYPE: Iran: Esfahan Province, about $250 \mathrm{~km}$ to $\mathrm{S}$ of Tehran, about $80 \mathrm{~km}$ to $\mathrm{N}$ of the Esfahan City, to the E of suburbs of Natanz settlement, Karkas huntingprohibited Region, to $\mathrm{S}$ of Abdaraz farm and $6.5 \mathrm{~km}$ to NE of Kalherud village, 51 $36^{\prime} 58^{\prime \prime}$ E $33^{\circ} 24^{\prime} 38^{\prime \prime}$ N, 2530 $\mathrm{m}$ alt., community with Malva sylvestris L. var. silvestris, Bromus tectorum L., Valeriana cymbicarpa C.A. Mey., Amygdalus communis L., on rocks, 19.IV.2010 B. ZareiDarki (1336), S.J. Khajeddin, Safavi, Jabbari, Naghipur ( $K W-L$ - holotype);

Thallus $2-3 \mathrm{~cm}$ across, foliosus, often distinctly rosette-like; lobes $3-5(-7) \mathrm{mm}$ long and $(0.5-) 0.7-1.5$ $\mathrm{mm}$ wide somewhat widened towards the tips to $1.5-2$ mm wide, seem to be semiconvex to very convex and somewhat semi-tubular (to $0.3-0.4 \mathrm{~mm}$ thick) owing to that laminal edges distinctly bent downwards, while in section they are $180-200(-250) \mu \mathrm{m}$ thick, and only at the edges to $0.3-0.4(-0.45) \mathrm{mm}$ thick, from single and somewhat distant each other to scarsely divided on 2-3 secondary lobules $2-3 \mathrm{~mm}$ long and almost the same width, total width of the whole lobes with secondary lobules $1.5-3 \mathrm{~mm}$ wide. 
In section upper cortex 24-36 $\mu \mathrm{m}$ thick, paraplectenchymatous, with large cell lumina to $7-12 \mu \mathrm{m}$ diam./across; medulla mainly lax $100-150 \mu \mathrm{m}$ thick, often with hollow at the edges (and 200-250(200) $\mu \mathrm{m}$ thick; lower cortical layer rather thin, 15$20(-25) \mu \mathrm{m}$ thick, paraplectenchymatous, with small cell lumina to $3-5(-7) \mu \mathrm{m}$ diam./across; algal layer a. $50 \mu \mathrm{m}$ thick, not continuous, in pseudocyphellae portions absent; lower surface often undulating and in section may resemble hapter-like formations while any specialized organs of attachment to the substrate are absent; in pseudocyphellae - hyphae may be similar to scleroplectenchyma, but in fact they are close to textura intricata (separate hyphae to $5.2 \mu \mathrm{m}$ diam., and lumina $1-1.5 \mu \mathrm{m}$ diam. observed). Upper surface very uneven owing to numerous pseudocyphellae; pseudocyphellae especially numerous on older lobes (lorger of $4 \mathrm{~mm}$ long), while younger lobes (less of $4 \mathrm{~mm}$ long) usually without pseudocyphellae; dull brownish-orange seem to be with pruine (while at large magnification more of X30 - without pruine); in the centre of thallus lobes often with whitish sides; rarely with transversal fissures/ cracks and exfoliating in the central portions of thallus (similarly to Caloplaca anularis Clauzade \& Poelt or C. zeravshanica Kudratov \& S.Y. Kondr.).

Apothecia to $1-1.5 \mathrm{~mm}$ diam., (and to $0.25-0.3$ ($0.45) \mathrm{mm}$ thick in section), especially numerous in the central portion of thallus, distinctly uplifted on attenuated stipae, lecanorinae, while often disc more or less slightly convex and thalline exciple well developed only on underside, cortical layer of thalline exciple 24$36(-48) \mu \mathrm{m}$ thick, paraplectenchymatous or palisade with large more or less rounded or vertically elongated cell lumina (5-)7-12(-17) $\mu \mathrm{m}$ diam./across; true exciple mainly well developed only in the uppermost lateral portion, 50-72(-96) $\mu \mathrm{m}$ wide, paraplectenchymatous, with cell lumina 5-7(-9.6) $\mu \mathrm{m}$ diam./across; in lower lateral and basal portion disappearing or to $12 \mu \mathrm{m}$ thick, textura intricata; hymenium 70-80 $\mu \mathrm{m}$ high; paraphyses widened towards the tips to $5-7 \mu \mathrm{m}$ wide (in $\mathrm{K}: 7-8.5 \mu \mathrm{m}$ diam.); subhymenium $20-30 \mu \mathrm{m}$ thick, very thin; algal zone underlying subhymenium or true exciple very thick $100-120(-150) \mu \mathrm{m}$ thick, or algae are in lax medullar; medullar without hollow; asci 8 -spored, while usually only 1-2 adult bipolar together with abortive 1-septate ascospores seen; ascospores mainly ellipsoid with rounded ends, and rounded cell lumina, (8-) $9.5-13.5 \times(4-) 6.5-8.5 \mu \mathrm{m}$ in water and $(9.5-) 10.5-14(-15) \times(5.5-) 6.5-9.5 \mu \mathrm{m}$ in $\mathrm{K}$; septum
$2.2-3.5(-4) \mu \mathrm{m}$ wide in water and $(3-) 3.5-5.5(-7)$ $\mu \mathrm{m}$ wide in $\mathrm{K}$.

Chemistry: Thallus $\mathrm{K}+$ purple. Constituents: parietin (major compound), teloschistin, fallacinal, parietinic acid and emodin (traces).

Ecology: Known from the alpine or cold desert regions, where it grows abundantly on large siliceous boulders (rocks) both on subvertical and horizontal faces exposed to the sun.

Distribution: This species is presently known from distant localities in the Palearctic (Europe, Asia and North Africa).

Etymology: It is named after Esfahan Province of Iran, where type collection was made.

\section{Taxonomic notes:}

Zeroviella esfahanensis is similar to Z. mandschurica (Zahlbr.) S.Y. Kondr. \& Kärnefelt, but differs in having much shorter $(3-5(-7) \mathrm{mm}$ vs. $8-17 \mathrm{~mm}$ long) and larger range of width $(0.5-) 0.8-1.5 \mathrm{~mm}$ vs. $0.9-1$ $\mathrm{mm}$ wide) lobes, and in having narrower total width of lobes (1.5-3 $\mathrm{mm}$ vs. $3.5-4.5 \mathrm{~mm}$ wide), in having epruinose apothecium disc (vs. with white pruine in Z. mandschurica), in having paraplectenchymatous true exciple well developed in the uppermost lateral portion (vs. scleroplectenchymatous and much wider in basal portion in $R$. mandshurica) and in having narrower ascospore septum $(2.2-3.5 \mu \mathrm{m}$ vs. $4-6 \mu \mathrm{m}$ wide), as well as in lack of scleroplectenchyma in cortex of thalline exciple.

Zeroviella esfahanensis is similar to Rusavskia elegans (Link) S.Y. Kondr. \& Kärnefelt but differs in having much shorter (3-5 vs. 6-7 mm long) and much wider (0.8-1.5 mm vs. $0.5-1 \mathrm{~mm}$ wide) thalline lobes, in having both cortical layers paraplectenchymatous (vs. mainly scleroplectenchymatous in $R$. elegans), in having much thinner (50-72 $\mu \mathrm{m}$ vs. $400-450 \mu \mathrm{m}$ wide) paraplectenchymatous (vs. scleroplectenchymatous in $R$. elegans) true exciple, in having somewhat shorter ascospores (10-13 $\mu \mathrm{m}$ vs. 11-16 $\mu \mathrm{m}$ long), and not becoming much wider in $\mathrm{K}$, as well as in having narrower ascospore septum (2.2-3.5 $\mu \mathrm{m}$ vs. 5-6 $\mu \mathrm{m}$ wide), and in the lack of hollow in the medullar layer.

Zeroviella esfahanensis is similar to Caloplaca vorukhica S.Y. Kondr. \& Kudratov, but differs in having smaller thallus and thalline lobes, in having numerous pseudocyphellae, in having much less developed true exciple (50-70 $\mu \mathrm{m}$ vs. $400-450 \mu \mathrm{m}$ wide in the lateral portion and to $12 \mu \mathrm{m}$ thick vs. $90-110(-120) \mu \mathrm{m}$ thick in basal portion); in having much smaller/shorter 
ascospores $(9.5-13.5 \times 7-8 \mu \mathrm{m}$ vs. $11-16 \times 6-8 \mu \mathrm{m})$, in having narrower ascospore septum $(2.2-3.5 \mu \mathrm{m}$ vs. 5-6 $\mu \mathrm{m}$ wide), and in the lack of hollow medulla, in the lack of scleroplectenchymatous tissue in both upper and lower cortical layers, as well as in the lack of papillae in the centre of thallus (Kondratyuk et al., 2004).

The status of Zeroviella esfahanensis after molecular data is still under special study. It is in somewhat intermediate position between the Zeroviella and Rusavskia branches. After ITS nrDNA analysis the Zeroviella esfahanensis branch is within the Zeroviella clade while after the $12 \mathrm{~S} \mathrm{mtSSU}$ analysis it is a member of the Rusavskia clade. Zeroviella esfahanensis is here included into the genus Zeroviella because after data of combined phylogenetic analysis it is a member of the Zeroviella clade (Fig. 1).

Other selected specimens examined. Iran: Esfahan Province, about $80 \mathrm{~km}$ to the north of the Esfahan City, to the east of suburbs of Natanz settlement, Karkas HuntingProhibited Region, to the south of Abdaraz farm and $7 \mathrm{~km}$ to the north-east of Kalherud village, 51 ${ }^{\circ} 32^{\prime} 06^{\prime \prime} \mathrm{E} 33^{\circ} 22^{\prime} 26^{\prime \prime} \mathrm{N}$, $2380 \mathrm{~m}$ alt., plant communities with Delphinium lanigerum Boiss. \& Hohen. Melica persica Kunth, Pistacia atlantica Desf., on rock, 15.03.2010 and 29.08.2010 B. Zarei-Darki (2[1]), Khajeddin, Safavi, Jabbari $(K W-L) ; 15 \mathrm{~km}$ to the north of Soh settlement and about $12 \mathrm{~km}$ to the west of

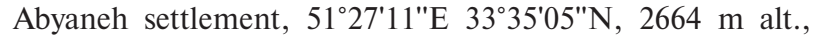
plant communities with Anemona biflora DC. / Pseudosedum multicaule /Bromus tomentellus Boiss. / Tulipa biflora Pall./ Euphorbia heteradenia Jaub. \& Spach, on rock, 02.05.2010 B. Zarei-Darki (15), Khajeddin, Safavi, Naghipur, Jabbari $(K W-L)$; to the south of the Saleh Abad farm, $13 \mathrm{~km}$ to the south-east of Kalherud settlement, 51 $40^{\prime} 59^{\prime \prime} \mathrm{E}, 33^{\circ} 18^{\prime} 45^{\prime \prime} \mathrm{N}$, 2090 m alt., plant communities with Euphorbia bungei Boiss. Malcolmia africana (L.) R. Br., Nonnea pulla (L.) DC., Tulipa biflora, on rock, 29.08.2010 B.Zarei-Darki (1428), Khajeddin, Safavi, Naghipur, Jabbari $(K W-L)$; to the south of Abderaz farm and nearly $5 \mathrm{Km}$ to the north-east of Kalherud settlement, $51^{\circ} 49^{\prime} 1^{\prime \prime E}, 33^{\circ} 32^{\prime} 56^{\prime \prime} \mathrm{N}, 1846 \mathrm{~m}$ alt., plant communities with Astragalus glaucacathus Fisch. / Arrhenatherum kotschyi Boiss./Carduus pycnocephalus L. / Andrachne telephioides / Centaurea iberica Trevir. ex Spreng. / Phalaris minor Retz., on rocks, 29.08.2010 B. Zarei-Darki (1936), Khajeddin, Safavi, Jabbari, Naghipur $(K W-L) ; 13 \mathrm{Km}$ to the north of Soh and Tajrepaeen farm, 51 $27^{\prime} 33^{\prime \prime E}, 33^{\circ} 35^{\prime} 23^{\prime \prime} \mathrm{N}, 2733 \mathrm{~m}$ alt., plant communities with Anemona biflora /Pseudosedum multicaule/ Bromus tomentellus / Tulipa biflora /Euphorbia heteradenia, on rocks, 02.05.2010, 29.08.2010 B. Zarei-Darki (2851), Khajeddin, Safavi, Naghipur, Jabbari $(K W-L)$; Varguran village, $6 \mathrm{~km}$ to the north of Targh settlement, towards Natanz settlement, 51 $48^{\prime} 52^{\prime \prime} \mathrm{E}, 33^{\circ} 24^{\prime} 43^{\prime \prime} \mathrm{N}, 2127 \mathrm{~m}$ alt., plant communities with Psychrogeton amorphoglossus / Melica persica / Lepidium persicum Boiss. / Helichrysum polyphyllum Ledeb., rock, 26.05.2010 and 29.08.2010 B. Zarei-Darki (3195), Khajeddin, Safavi, Naghipur, Jabbari $(K W-L) ; 1 \mathrm{~km}$ to the north of Kesheh village, 51 $46^{\prime} 31^{\prime \prime} \mathrm{E}, 33^{\circ} 24^{\prime} 24^{\prime \prime} \mathrm{N}, 2550$ m alt., plant communities with Malcolmia africana, Euphorbia bungei, Nonnea pulla, Tulipa biflora, on rocks, 18.04.2010
B. Zarei-Darki (1201), Khajeddin, Safavi, Naghipur ( $K W$ $L)$; to the north-east of Tajrehbala farm, $11 \mathrm{~km}$ to the east of Abyaneh settlement, 51 $28^{\prime} 12^{\prime \prime} \mathrm{E}, 33^{\circ} 36^{\prime} 00^{\prime \prime} \mathrm{N}, 2859 \mathrm{~m}$ alt., plant communities with Pseudosedum multicaule / Bromus tomentellus / Tulipa biflora / Euphorbia heteradenia, on rocks, 02.05.2010 and 29.08.2010 B. Zarei-Darki (2117), Hajeddin, Safavi, Jabbari, Naghipur (TEH); $2 \mathrm{~km}$ to the south of Bidhend village, $14 \mathrm{~km}$ to the east of Natanz settlement, $51^{\circ} 46^{\prime} 60^{\prime \prime} \mathrm{E}, 33^{\circ} 29^{\prime} 20^{\prime \prime} \mathrm{N}, 2465 \mathrm{~m}$ alt., plant communities with Descurainia sophia (L.)/Myostis stricta Link / Nonnea pulla (L.) DC. / Hyoscyamus pusillus L. / Adonis aestivalis L., on rocks, 04.05.2010 B. Zarei-Darki (2349), Khajeddin, Safavi, Naghipur $(K W-L)$; Varguran village, $6 \mathrm{~km}$ to the north of Targh settlement, towards Natanz settlement, 51 $48^{\prime} 52^{\prime \prime} \mathrm{E}$, $33^{\circ} 24^{\prime} 43^{\prime \prime} \mathrm{N}, 2127 \mathrm{~m}$ alt., plant communities with Psychrogeton amorphoglossus / Melica persica / Lepidium persicum / Helichrysum polyphyllum, 26.05.2010 and 29.08.2010 B. ZareiDarki (3189), Khajeddin, Safavi, Naghipur, Jabbari $(K W-L)$.

Iran, Esfahan and Markazi Province, about $200 \mathrm{~km}$ to the south of Tehran, about $85 \mathrm{~km}$ to the north of Esfahan City, between Meymeh and Delijan settlements, Mooteh Wildlife Refuge, $6 \mathrm{~km}$ to the north-east of Abbaric check-point and to the west of Palangi Mountain. 51 $41^{\prime} 31^{\prime \prime E}, 33^{\circ} 40^{\prime} 37^{\prime \prime} \mathrm{N}$, $2140 \mathrm{~m}$ alt., plant communities with Artemisia sieberi Besser, Acanthophyllum spinosum C.A. Mey., Echinophora platyloba DC., on rocks., 21.07.2010 and 21.01.2011 B. Zarei-Darki (441 [2]), Khajeddin, Naghipur, Jabbari $(K W-L) ; 5.5 \mathrm{~km}$ to the Zarkan settlement and to the north-west of Mast Mountain. $50^{\circ} 50^{\prime} 11^{\prime \prime E}, 33^{\circ} 26^{\prime} 37^{\prime \prime} \mathrm{N}, 2266 \mathrm{~m}$ alt., plant communities with Artemisia sieberi, Acanthophyllum spinosum, Echinophora platyloba, on rocks, 28.05.2010 and 21.07.2010 B. ZareiDarki (1573), Khajeddin, Naghipur, Jabbari $(K W-L)$.

[Spain]: Canary Islands: Tenerife, to the north of Botanical Garden of Teide National Park, 16³3'91.2"W, 26 17'70.2"N, $2184 \mathrm{~m}$ alt., alpine zone with Legium (Ligulaceae) and Brassicaceae dominated representatives, mainly on shaded and north-facing surfaces of rocks, 12.01.2009 S. Kondratyuk 20909, I. Kärnefelt, A. Thell \& T. Feuerer $(K W-L)$.

Totally 14 species previously included in the genus Xanthoria were combined to the genus Rusavskia in original description of this genus (Kondratyuk, Kärnefelt, 2003), while only 5 species (Rusavskia elegans, type species; $R$. aspera (Savicz) S.Y. Kondr. \& Kärnefelt, and $R$. ectaniza (Boistel) S.Y.Kondr. \& Kärnefelt, as well as isidiate species $R$. dasanensis S.Y. Kondr., I. Galanina et J.-S. Hur, and sorediate taxon $R$. sorediata, [see also Kondratyuk et al., 2013c; Ahti et al., 2015]) are currently confirmed to the genus Rusavskia (as Rusavskia s.str.) after molecular data.

\section{New combinations}

Zeroviella coreana (S.Y. Kondr. \& J.-S. Hur) S.Y. Kondr. \& J.-S. Hur, comb. nov. - MycoBank No. MB 814862. Basionym: Rusavskia coreana S.Y. Kondr. \& J.S. Hur, in Kondratyuk et al., Acta Botanica Hungarica 57(1-2): 118 (2015). 
Zeroviella digitata (S.Y. Kondr. in Kondratyuk \& Kärnefelt) S.Y. Kondr. \& J.-S. Hur, comb. nov. MycoBank No. MB 814864. Basionym: Xanthoria digitata S.Y. Kondratyuk in Kondratyuk \& Kärnefelt, Ukrainian Botanical Journal, 60 (2): 121 (2003). Synonym: Rusavskia digitata (S.Y. Kondr.) S.Y. Kondr. \& Kärnefelt, Ukrainian Botanical Journal, 60 (4): 433 (2003).

Zeroviella domogledensis (Vězda) S.Y. Kondr. \& J.-S. Hur, comb. nov. - MycoBank No. MB 814865. Basionym: Xanthoria domogledensis Vězda, Lichenes sel. Exsicc. Fasc. 52 No. 1294: 6 (1975). - Synonym: Rusavskia domogledensis (Vězda) S.Y. Kondr. \& Kärnefelt, Ukrainian Botanical Journal, 60 (4): 433 (2003).

Zeroviella laxa (Müll. Arg.) S.Y. Kondr. \& J.-S. Hur, comb. nov. - MycoBank No. MB 814879 Basionym: Amphiloma elegans var. laxum Müll. Arg., Flora, Regensburg 67: 465 (1884).

Zeroviella mandschurica (A. Zahlbr.) S.Y. Kondr. \& J.-S. Hur, comb. nov. - MycoBank No. MB 814868. Basionym: Xanthoria parietina (L.) Beltram. var. mandschurica A. Zahlbr., Ann. Mycolog., 29: 85 (1931). - Synonym: Rusavskia mandschurica (A. Zahlbr.) S.Y. Kondr. \& Kärnefelt, Ukrainian Botanical Journal, 60 (4): 434 (2003).

Zeroviella papillifera (Vain.) S.Y. Kondr. \& J.-S. Hur, comb. nov. - MycoBank No. MB 814869. Basionym: Placodium papilliferum Vainio, Termeszetr. Füzetek, 22: 294 (1899). - Synonym: Rusavskia papillifera (Vain.) S.Y. Kondr. \& Kärnefelt, Ukrainian Botanical Journal, 60 (4): 434 (2003).

Zeroviella ussurica (S.Y. Kondr. \& J.-S. Hur) S.Y. Kondr. \& J.-S. Hur, comb. nov. - MycoBank No. MB 814870. Basionym: Rusavskia ussurica S.Y. Kondr. \& J.S. Hur, in Kondratyuk et al., Acta Botanica Hungarica 57(1-2): 122 (2015).

Zeroviella domogledensis was previously included in the genus Zeroviella. This opinion is in urgent need of further confirmation by molecular data.

Furthermore, the following new combinations are proposed for the taxa which position is recently confirmed by molecular data:

Blastenia catalinae (H. Magn.) E.D. Rudolf, comb. nov. - MycoBank No. MB 814871. Basionym: Caloplaca catalinae H. Magn., Bot. Notiser 71 (1944).
Fulgogasparrea brouardii (B. de Lesd.) S.Y. Kondr., comb. nov. - MycoBank No. MB 814872. Basionym: Placodium brouardii B. de Lesd., Lich. Mexique: 11 (1914). - Synonym: Caloplaca brouardii (B. de Lesd.) Zahlbr., Cat. Lich. Univers. 7: 220 (1931).

Scythioria duritzii (H. Magn.) S.Y. Kondr., comb. nov. - MycoBank No. MB 814873 Basionym: Caloplaca durietzii H. Magn., Bot. Notiser: 188 (1953).

Scythioria flavogranulosa (Arup) S.Y. Kondr., comb. nov. - MycoBank No. MB 814874. Basionym: Caloplaca flavogranulosa Arup, Bryologist 96: 598 (1993). - Synonym: Polycauliona flavogranulosa (Arup) Arup, Frödén \& Søchting, Nordic Journal of Botany 31: 51 (2013).

Sirenophila cliffwetmorei (S.Y. Kondr. \& Kärnefelt) S.Y. Kondr., comb. nov. - MycoBank No. MB 814875. Basionym: Caloplaca cliffwetmorei S.Y. Kondr. \& Kärnefelt in Kondratyuk et al., Bibliotheca Lichenologica (Diversity of Lichenology - Anniversary Volume. Thell, A., Seaward, M. R. D. \& Feurer, T. (eds)) 100: 236 (2009).

Squamulea nesodes (Poelt \& Nimis) S.Y. Kondr., comb. nov. - MycoBank No. MB 814876. Basionym: Caloplaca inconnexa var. nesodes Poelt \& Nimis, in Nimis \& Poelt, Stud. Geobot. 7 (Suppl. 1): 66 (1987). Synonym: Caloplaca inconnexa subsp. nesodes (Poelt \& Nimis) CL. Roux, in Roux et al., Bull. Soc. Linn. Provence 57: 83 (2006).

Villophora microphyllina (Tuck.) S.Y. Kondr., comb. nov. - MycoBank No. MB 814877. Basionym: Placodium microphyllinum Tuck., Synops. North. Americ. Lich. 1: 174 (1882). - Synonym: Caloplaca microphyllina (Tuck.) Hasse, Contr. U.S. natnl. Herb. 17: 114 (1913).

\section{Conclusion}

Molecular studies of the further specimens of the genera Zeroviella and Rusavskia s.l. from the African and South American continents are in progress and their status will be clarified in the nearest future.

\section{Acknowledgement}

We are thankful to I.A. Galanina (Vladivostok, Russia) and S.-O. Oh (Sunchon, South Korea) for the help with getting voucher specimens for molecular study.

Financial support of this study in parts from Ministry of Science and Education of Ukraine (M/90-2015-285) for SK is deeply acknowledged. 


\section{REFERENCES}

Ahti T., Kondratyuk S.Y., Kärnefelt I., Thell A. Nomenclatural corrections and notes on some taxa in the Teloschistaceae (lichenized ascomycetes), Graphis Scripta, 2015, 27(1-2), pp. 37-41.

Arup U., Søchting U., Frödén P. A new taxonomy of the family Teloschistaceae, Nord. J. Bot, 2013a, 31(1), pp. 16-83.

Arup U., Søchting U., Frödén P., Addendum to 'A new taxonomy of the family Teloschistaceae', Nord. J. Bot, 2013b, 31(2), p. 256.

Dyer P.S., Murtagh G.J. Variation in the ribosomal ITS-sequence of the lichens Buellia frigida and Xanthoria elegans from the Vestfold Hills, eastern Antarctica, Lichenologist (Lond.), 2001, 33(2), pp.151-159.

Ekman S. PCR optimization and troubleshooting, with special reference to the amplification of ribosomal DNA in lichenized fungi, Lichenologist, 1999, 31(5), pp. 517-531.

Fedorenko N.M., Stenroos S., Thell A., Kärnefelt I., Kondratyuk S.Y. A phylogenetic analysis of xanthorioid lichens (Teloschistaceae, Ascomycota) based on ITS and mtSSU sequences, Bibl. Lichenol., 2009, 100, pp. 49-84.

Fedorenko N.M., Stenroos S., Thell A., Kärnefelt I., Elix J.A., Hur J.S., Kondratuyk S.Y. Molecular phylogeny of xanthorioid lichens (Teloschistaceae, Ascomycota), with notes on their morphology, Bibl. Lichenol., 2012, 108, pp. 45-64.

Gaya E., Lutzoni F., Zoller S., Navarro-Rosinés P. Phylogenetic study of Fulgensia and allied Caloplaca and Xanthoria species (Teloschistaceae, lichen-forming ascomycota), Amer. J. Bot., 2003, 90, pp. 1095-1103.

Gaya E., Navarro-Rosinés P., Llimona X., Hladun N., Lutzoni F. Phylogenetic reassessment of the Teloschistaceae (lichen-forming Ascomycota, Lecanoromycetes), Mycol. Res, 2008, 112, pp. 528-546.

Gaya E., Högnabba F., Holguin Á., Molnár K., FernándezBrime S., Stenroos S., Arup U., Søchting U., van den Boom P., Lücking R., Sipman H.J.M., Lutzoni F. Implementing a cumulative supermatrix approach for a comprehensive phylogentic study of the Teloschistales (Pezizomycotina, Ascomycota), Mol. Phyl. Evol, 2012, 63, pp. 374-387.

Gardes M., Bruns T.D. ITS primers with enhanced specificity for basidiomycetes - application to the identification of mycorrhizae and rusts, Mol. Ecol., 1993, 2, pp. 113-118.

Kärnefelt I. Morphology and phylogeny in the Teloschistales, Cryptogamic Botany, 1989, 1, pp. 147-203.

Kondratyuk S.Ya., Kärnefelt I. Revision of three natural groups of xanthorioid lichens (Teloschistaceae, Ascomycota), Ukr. Bot. J., 2003, 60(4), pp. 443-453.

Kondratyuk S.Ya., Oxner A.N., Khodosovtsev A.Ye. Caloplaca. In: Operedelitel lishajnikov Rossii. Vol. 9. Fuscideaceae, Teloschistaceae. Eds M.P. Andreev, O.G. Roms, St. Peterburg: Nauka, 2004, pp. 38-236. [Кондратюк С.Я., Окснер А.Н., Ходосовцев А.Е. Caloplaca //Oпределитель лишайников России, Т. 9.
Фусиидеевые, Телосхистовые /Ред. М.П. Андреев, Е.Г. Ромс. - СПб.: Наука, 2004. - С. 38-236].

Kondratyuk S.Y., Lőkös L., Zarei-Darki B., Haji Moniri M., Tchabanenko S.I., Galanina I., Yakovchenko L., Hooshmand F., Ezhkin A.K., Hur J.S. Five new Caloplaca species (Teloschistaceae, Ascomycota) from Asia, Acta Bot. Hung., 2013a, 55(1-2), pp. 41-60.

Kondratyuk S., Jeong M.H., Yu N.H., Kärnefelt I., Thell A., Elix J.A., Kim J., Kondratyuk A.S., Hur J.S. Four new genera of Teloschistoid lichens (Teloschistaceae, Ascomycota) based on molecular phylogeny, Acta Bot. Hung., 2013b, 55(3-4), pp. 251-274.

Kondratyuk S., Yatsyna A.P., Lőkös L., Galanina I., Haji Moniri M., Hur J.-S. Three new Xanthoria and Rusavskia species (Teloschistaceae, Ascomycota) from Europe, Acta Bot. Hung., 2013c, 55(3-4), pp. 351-365.

Kondratyuk S.Ya., Tschabanenko S.I., Elix J.A., Oh S.-O., Thell A., Hur J.-S. Nipponoparmelia perplicata sp. nov. (Parmeliaceae, Ascomycota) from eastern Asia, Mycotaxon, 2013d, 126, pp. 37-44.

Kondratyuk S.Y., Jeong M.H., Yu N.N., Kärnefelt I., Thell A., Elix J.A., Kim J., Kondratiuk A.S., Hur J.S. A revised taxonomy for the subfamily Caloplacoideae (Teloschistaceae, Ascomycota) based on molecular phylogeny, Acta Bot. Hung., 2014a, 56(1-2), pp. 93-123.

Kondratyuk S.Ya., Kärnefelt I., Thell A., Elix J.A., Kim J., Jeong M.H., Yu N.H., Kondratiuk A.S., Hur J.S. A revised taxonomy of the subfamily Xanthorioideae (Teloschistaceae, Ascomycota) based on molecular phylogeny, Acta Bot. Hung., 2014b, 56(1-2), pp. 141-178.

Kondratyuk, S.Ya., Lőkös L., Kim J., Jeong M.-H., Kondratiuk A. S., Oh S.-O., Hur J.-S. Kashiwadia gen. nov. (Physciaceae, Lichen-Forming Ascomycota) proved by phylogenetic analysis of the Eastern Asian Physciaceae, Acta Bot. Hung., 2014c, 56(3-4), pp. 367-376.

Kondratyuk, S.Ya., Kärnefelt, I., Thell, A., Elix, J. A., Kim, J., Kondratiuk, A.S., Hur, J.-S. Tassiloa, a new genus in the Teloschistaceae (lichenized ascomycetes), Graphis Scripta, 2015a, 27(1-2), pp. 22-26.

Kondratyuk, S.Y., Lőkös L., E. Farkas, Oh S.-O., Hur J.-S. New and noteworthy lichen-forming and lichenicolous fungi, 2, Acta Bot. Hung., 2015b, 57(1-2), pp. 77-141.

Kondratyuk S.Y., Lőkös L., Kim J.A., Kondratiuk A.S., Jeong M.H., Jang S.H., Oh S.-O., Hur J.-S. Three New Monotypic Genera of the Caloplacoid Lichens (Teloschistaceae, Lichen-Forming Ascomycetes), Mycobiology, 2015c, 43(3), pp. 195-202, available at: http://dx.doi. org/10.5941/MYCO.2015.43.3.00

Kondratyuk S.Ya., Kärnefelt I., Thell A., Elix J. A., Kim J., Kondratiuk A.S., Hur J.-S. Brownlielloideae, a new subfamily in the Teloschistaceae (Lecanoromycetes, Ascomycota), Acta Bot. Hung., 2015d, 57(3-4), pp. 321-341. doi: 10.1556/ABot.57.2015.3-4.6

Lindblom L., Ekman S. Molecular evidence supports the distinction between Xanthoria parietina and X. aureola (Teloschistaceae, lichenized Ascomycota), Mycol. Res., 2005, 109 (PT 2), pp. 187-199. 
Orange A., James P.W., White F.J. Microchemical methods for the identification of lichens. 2nd ed., London: British Lichen Society, 2010, $101 \mathrm{pp}$.

Søchting U., Kärnefelt I., Kondratyuk S. Revision of Xanthomendoza (Teloschistaceae, Lecanorales) based on morphology, anatomy, secondary metabolites and molecular data, Mitt. Inst. Allg. Bot. Hamburg, 2002, 30-32, pp. 225-240.

Søchting U., Sogaard M.Z., Elix J.A., Arup U., Elvebakk A., Sancho L.G. Catenarina (Teloschistaceae, Ascomycota), a new Southern Hemisphere genus with 7-chlorocatenarin, Lichenologist, 2014a, 46(2), pp. 175-187.

Søchting U., Garrido-Benavent I., Seppelt R., Castello M., Pérez-Ortega S., De Los Ríos Murillo A., Sancho L.G., Frödén P., Arup U. Charcotiana and Amundsenia, two new genera in Teloschistaceae (lichenized Ascomycota, subfamily Xanthorioideae) hosting two new species from continental Antarctica, and Austroplaca frigida, a new name for a continental Antarctic species, Lichenologist, 2014b, 46(6), pp. 763-782.

Tamura K., Peterson D., Peterson N., Stecher G., Nei M., Kumar S. MEGA5: molecular evolutionary genetics analysis using maximum likelihood, evolutionary distance, and maximum parsimony methods, Mol. Biol. Evol., 2011, 28, pp. 2731-2739.

Vilgalys R., Hester M. Rapid genetic identification and mapping of enzymatically amplified ribosomal DNA from several Cryptococcus species, J. Bacteriol, 1990, 172(8), pp. 4238-4246.

White T.J., Bruns T., Lee S., Taylor J. Amplification and direct sequencing of fungal ribosomal RNA genes for phylogenetics. In: PCR protocols: a guide to methods and applications, 1990, 38, pp. 315-322.

Recommended by

Submitted 15.10.2015

I.O.Dudka

Кондратюк С. Я. ${ }^{1}$, Кім Ю. А. ${ }^{2}$, Ю Н.-Н. ${ }^{2}$, Джеонг М.-Х. ${ }^{2}$, Янг С.-Х., Кондратюк А. С. ${ }^{2,3}$, Зареї-Даркі Б. ${ }^{4}$, Хо Д.-С. ${ }^{2}$

Zeroviella, новий рід ксанторіоїдних лишайників

(Teloschistaceae, Ascomycota), підтверджений даними тригенної філогенії. - Укр. ботан. журн. - 2015. - 72(6): $574-584$.

${ }^{1}$ Інститут ботаніки імені М.Г. Холодного НАН України вул. Терещенківська, 2, м. Київ, 01004, Україна

${ }^{2}$ Корейський інститут вивчення лишайників Сунчон, Південна Корея

${ }^{3}$ Навчально-науковий центр центр «Інститут біології» Київського національного університету імені Тараса Шевченка вул. Володимирська, 64/3, м. Київ, 01601, Україна

${ }^{4}$ Університет Тарбіат Модарес

Джалал Але Ахмад шосе, 14115-318, Тегеран, Іран

Новий рід Zeroviella S.Y. Kondr. \& J.-S. Hur (Xanthorioideae, Teloschistaceae) запропонований для широко розповсюдженої в Палеарктиці Rusavskia papillifera-групи видів на основі комбінованого філогенетичного аналізу, що грунтується на ITS і великій субодиниці (LSU) ядерної ДНК та $12 \mathrm{~S}$ малої субодиниці мітохондріальної ДНК. Описано і проілюстровано новий для науки вид Zeroviella esfahanensis S.Y. Kondr., B. Zarei-Darki \& J.S. Hur. Запропоновано сім нових комбінацій для роду Zeroviella (зокрема для: Zeroviella coreana, Z. digitata, Z. domogledensis, Z. laxa, Z. mandschurica, Z. papillifera і Z. ussurica). Крім того, запропоновано сім нових комбінацій для представників різних родів родини Teloschistaceae (зокрема: Blastenia catalinae, Fulgogasparrea brouardii, Scythioria duritzii, Scythioria flavogranulosa, Sirenophila cliffwetmorei, Squamulea nesodes, i Villophora microphyllina), статус яких підтверджено сучасними молекулярними даними.

К л ю ч о в і с л о в а: Rusavskia, Zeroviella esfahanensis, Scythioria, Fulgogasparrea, Blastenia.

Кондратюк С.Я. ${ }^{1}$, Ким Ю.А. ${ }^{2}$, Ю Н.-Н. ${ }^{2}$, Джеонг М.-Х. ${ }^{2}$, Янг C.-Х. ${ }^{2}$, Кондратюк А.С. ${ }^{2,3}$, Зареи-Дарки Б. ${ }^{4}$, Хо Д.-С. ${ }^{2}$ Zeroviella, новый род ксанториоидных лишайников (Teloschistaceae, Ascomycota), подтвержденный данными молекулярной филогении. - Укр. ботан. журн. - 2015. 72(6): 574-584.

${ }^{1}$ Институт ботаники имени Н.Г. Холодного НАН Украины ул. Терещенковская, 2, г. Киев, 01004, Украина

${ }^{2}$ Корейский институт изучения лишайников г. Сунчон, Южная Корея

${ }^{3}$ Образовательно-научный центр «Институт биологии» Киевского национального университета имени Тараса Шевченко

ул. Владимирская, 64/3, г. Киев, 01601, Украина

${ }^{4}$ Университет Тарбиат Модарес

Джалал Але Ахмад шоссе, 14115-318, Тегеран, Иран

Новый род Zeroviella S.Y. Kondr. \& J.-S. Hur (Xanthorioideae, Teloschistaceae) предложен для широко распространенной в Палеарктике Rusavskia papillifera-группы видов на основании комбинированного филогенетического анализа, базирующегося на ITS и большой субъединице (LSU) ядерной ДНК и $12 \mathrm{~S}$ малой субъединице митохондриальной ДНК. Описан и проиллюстрирован новый для науки вид Zeroviella esfahanensis S.Y. Kondr., B. ZareiDarki \& J.S. Hur. Предложены семь новых комбинаций для рода Zeroviella (в частности, для: Zeroviella coreana, $Z$. digitata, Z. domogledensis, Z. laxa, Z. mandschurica, $Z$. papillifera и $Z$. ussurica). Кроме того, предложены семь новых комбинаций для представителей разных родов семейства Teloschistaceae (а именно: Blastenia catalinae, Fulgogasparrea brouardii, Scythioria duritzii, Scythioria flavogranulosa, Sirenophila cliffwetmorei, Squamulea nesodes и Villophora microphyllina), положение которых подтверждено современными молекулярными данными.

К л ю ч в в ы е с л о в а: Rusavskia, Zeroviella esfahanensis, Scythioria, Fulgogasparrea, Blastenia. 


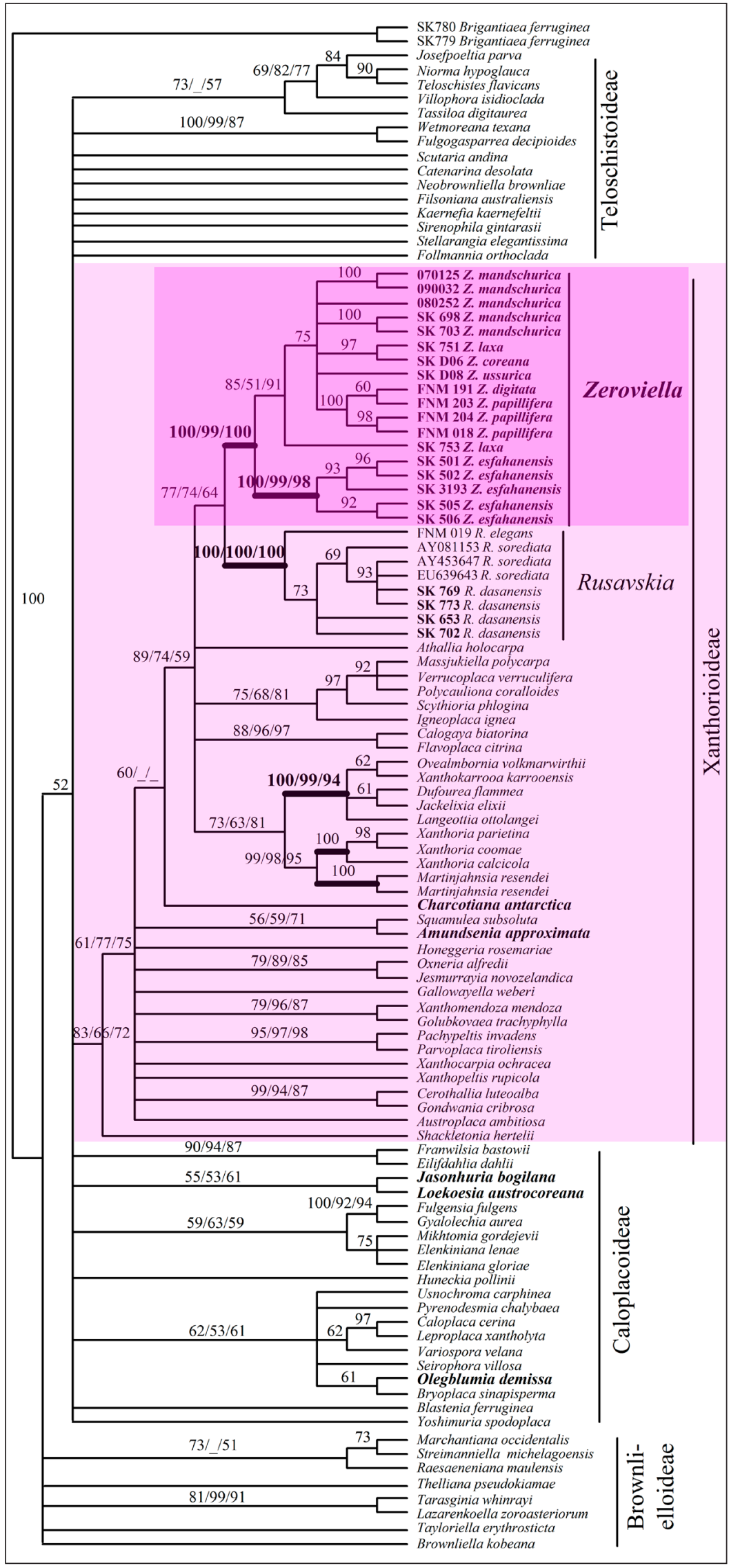

See paper of S.Y. Kondratyuk et al. in this issue (pp. 574-584)

Fig. 1. Phylogenetic tree of the Teloschistaceae with special attention to the Rusavskia clade (level of support of MP/ME/ML analysis are shown above nodes).

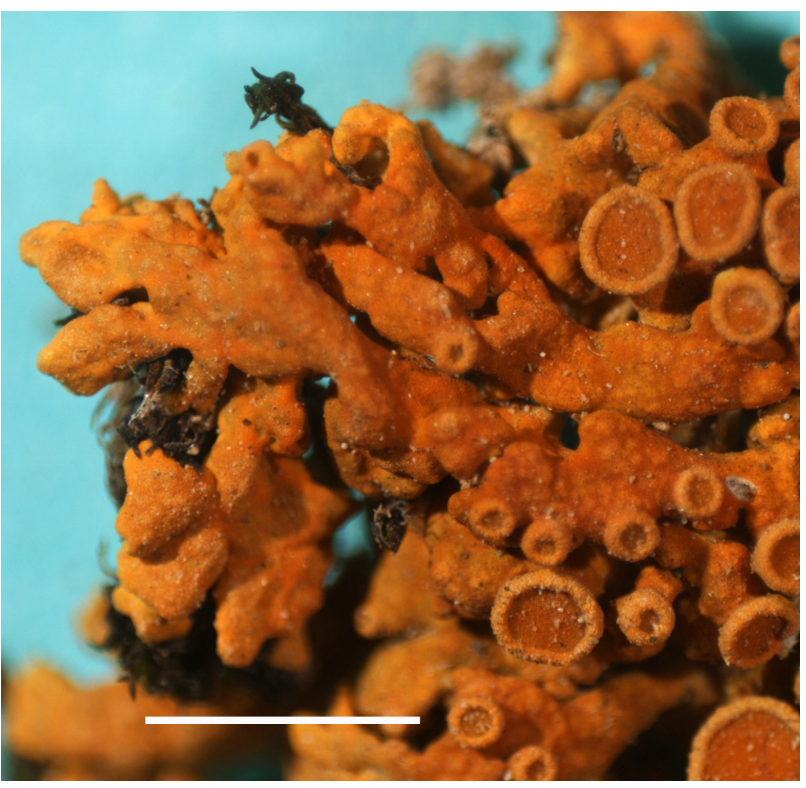

Fig. 2. Zeroviella esfahanensis (S.Y. Kondratyuk 20909, $K W-L$ ), general habit, scale $2 \mathrm{~mm}$.

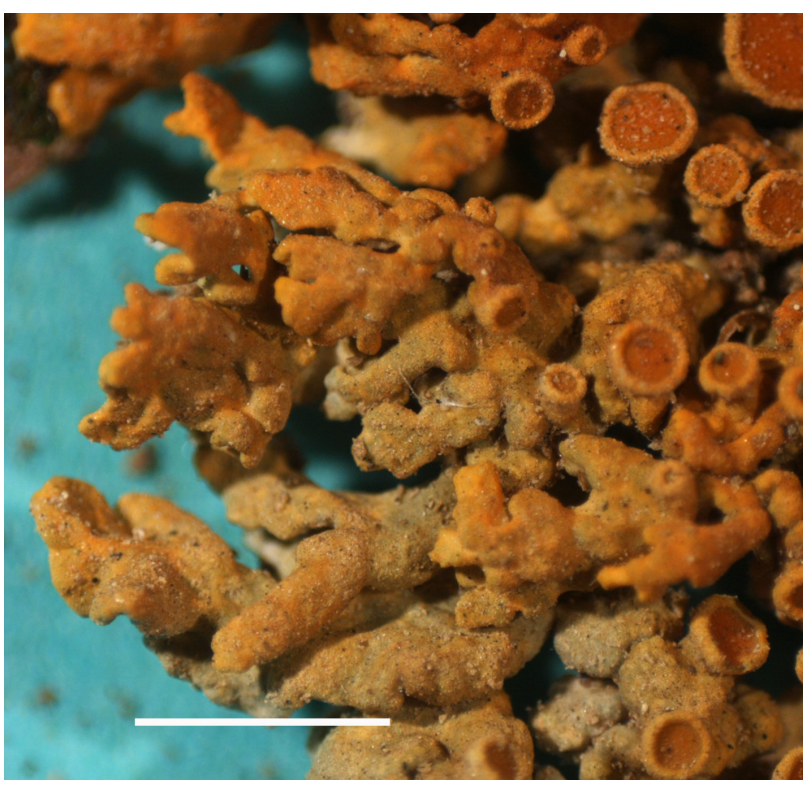

Fig. 3. Zeroviella esfahanensis (S.Y. Kondratyuk 20909, $K W-L$ ), enlarged portion of thalline lobes, scale $2 \mathrm{~mm}$. 